Independent Journal of Management \& Production (IJM\&P) ISSN: 2236-269X DOI: 10.14807/ijmp.v3i2.45

v. 3, n. 2, July - December 2012

\title{
DYING AESTHETIC SENSE OF BURNED OUT CORPORATE EMPLOYEES: A SOCIAL DISASTER
}

\author{
Mohammad Rizwan Junaid \\ Pakistan Institute of Management, Ministry of Industries, Govt. of Pakistan \\ E-mail: falsafi_28@yahoo.com
}

Submission: 08/11/2012

Accept: 05/12/2012

\section{ABSTRACT}

The intrinsic focus of this paper is to comprehend the causes of societal unrest, diminishing family values, absence of happiness, less or no involvement of corporate employees in social activities, increasing number of psycho patients, disturbed individuals, trackless-ness and a rising sense of alienation. The direct link of all these effects is with corporate world as overburdened, stressed and fatigued employees who are always under extreme stress referencing their jobs are losing or have lost most of their aesthetic sense and loss of aesthetic sense takes away the sense of beauty in objects, actions, relations and values and eventually Man appears mechanical like machines and this robotics damages the entire family life and death of family lives leave a hollow sphere in a society and these hollow spheres are on the rise round the globe these days. This paper attempts to highlight the causes and their corresponding effects and invite corporate stalwarts to read the writing of the wall without further wastage of time before it is too late.

Key-words: Corporate employees, Society, Disaster

\section{INTRODUCTION}

Balance is the most significant notion that depicts the intrinsic nature of every organic being, it can be defined as a state of bodily equilibrium; a stable mental or physical state, emotional stability; to bring into or maintain in a state of equilibrium; (Author, 2009). Every human in a society passes his life in a dualistic posture; one facet is outside the house as a productive individual in purely objective capacity and other inside the house or in the inner circle with family and friends in subjective capacity; and 
Independent Journal of Management \& Production (IJM\&P) ISSN: 2236-269X DOI: 10.14807/ijmp.v3i2.45

v. 3, n. 2, July - December 2012

needs extensive balance in these two aligned but altogether different spheres of life (Boswell, 2007); as, if the balance is not maintained and fundamental harmony is missing from this very relationship between Factory and Family, between company and companion and finally between work and welfare then we will be marching towards permanent disaster (Williams, 2000) in terms of family network, social values, pleasure, happiness, participation, societal involvement etc.

Aesthetics is a branch of philosophy deals with the nature of beauty, art, taste , creation and appreciation of beauty (Merriam-Webster, 2012); Personal aesthetics, as defined by Nadir Afonso in his geometry based aesthetic theory rational aesthetics within an intuitive art; is searching for absolute and the feelings of total exactitude (Galeria Alvarez, 1974) while social aesthetics is commonly participative/shared form of creativity, acceptance of socialist realism in the close context of society and with reference to individual existence (Vej, 2011).

The prime focus of this paper is to look into the sharp decline in aesthetic sense of corporate employees due to the significant work-life imblance and job related stress, and the aftereffects of this decline on the individual, family and social circle; furthermore, this paper derives the subsequent conclusion in the very right perpsective of identified organizational factors that causes the situation of distress and leaves an employee isolated from his own work, society and consequently himself.

\section{Significance of the Study}

There are number of studies available which discuss work-life balance as; (Caproni, 2004;Fincham, 2008;Caproni 1997;Byrne, 2005;McDougallb, 2004;Hughes, 2002;Ker, 2003;Blanchard, 2012; Berman, 2002) and many others and in continuation of the same there are noteworthy studies available in the area of job related stress as: (Kazmi, 2008; Rahim, 2010; Ahmad, 2009;Subbulaxmi, 2002; Mathur , 2011;NIOSH, 1999; EFILW, 2007; Shain, 1999; Higgins, 2005; Meglino, 1977) but there is a significant room available to look into the damage done by this imbalance and job related stress in terms of diminishing aesthetic sense among these corporate 
Independent Journal of Management \& Production (IJM\&P) ISSN: 2236-269X DOI: 10.14807/ijmp.v3i2.45

v. 3, n. 2, July - December 2012

employees and the relevant after affects on their families, societies and eventually themselves.

\section{Hypothesis}

$\mathrm{H}-1$ : There is a significant relationship between job related problems (imbalance and stress) and dying aesthetic sense of corporate employees

\section{Research Methodology}

The research methodology employed in this study is based upon previous studies, research initiatives, books, relevant articles and excerpts from experts' opinion in close relevance with the said subject and adequte to prove the formed hypothesis. These contributions with thorough relevancy pave the way towards building a solid and candid foundation needed to understand the issue and its different dimensions.

\section{REVIEW OF RELATED LITERATURE}

Aestheticism is a very old and established school of philosophy which took a new turn in the beginning of $19^{\text {th }}$ century; that was basically a movement in $19^{\text {th }}$ century focusing European region which emphasized the aesthetic value in performing Arts and Visual Arts (Denney, 2000) in contrast to political or socio-political value. It discussed the aesthetic sense in every physical object and Metaphysical essence.

Aesthetics as captioned above is a well-defined branch of philosophy which deals with Nature of beauty, Art and Taste with a prime focus upon creation and appreciation of beauty (Dictionary, 2011); it can further be elaborated as the study of sensory emotional values and often named as judgment of sentiments and tastes (Zangwill, 2008). Baumgarten, a renowned German philosopher, established aesthetics in order to frame the study of 'TASTE' as good and bad "taste," consequently good and bad art, connecting good taste with beauty (Gottlied, 2004). He took the discussion further and described 'taste' in its broader connotation, as the aptitude to judge according to the senses, rather than in the light of intellect. This specific judgment of taste is closely linked with the core and focused feelings of pleasure or displeasure. Aesthetics in its pure scientific form is, for Baumgarten, an inference of the rules or principles of imaginative or natural beauty derived from individual "taste." Immanuel 
Independent Journal of Management \& Production (IJM\&P) ISSN: 2236-269X DOI: 10.14807/ijmp.v3i2.45

v. 3, n. 2, July - December 2012

Kant (Kant, 1999) endorsed the said concept of Baugmarten and strongly advocated that an aesthetic judgment was idiosyncratic and subjective in that particular sense that it related to the internal feeling of pleasure or displeasure and not to any potentials in an exterior body. Immanuel Kant clarified this concept as beauty was fundamentally a clear sign of Morality as Morality stood for balance and every good soul enjoys nature in its fullest sense (Kant, 1964).

Aesthetic concept is not a set of rules being governed by further rules and focused regulations but needs an intensified form of sensitivity which can be called as taste, compassion or judgment and prime focus of this perceptive proportion is Unity as Art is expression and the very first benchmark which is needed for the approval is unity, an image of unity of things and mind which it expresses (Parker, 2003). Guy Sircello encircles aesthetic as the close combination of love (Sircello, 1975), beauty (Sircello, 1989) and sublimity (Sircello, 1993).

The Aesthetic sense with regard to physical object is primarily a search for balance, harmony and unity as all these attributes exemplify the physical completeness or 'totality' of an object. In fact, the fulcrum of aesthetic sense is in somewhere very deep within a human and it is that sense which encourages or motivates a person to appreciate beauty, any object of beauty influences one's personality and leads the person into a higher level of enjoying beauty (Xuxiao, 2010). It is noted here that aesthetic in its purest form is a scientific discipline which examines the common doctrines of advancement of man's aesthetic association to reality, and specifically of art as a particular form of social cognizance. It can be said that generally aesthetics examines the relationship between Man and reality and in particular their highest form, (Nedozchiwin, 1972).

Precisely, we are talking of a composite balance with in an object and between objects; the balance within an object reveals the composition of elements needed to form that object as their proportionate relationship and existence provides the sense of beauty and completeness and on the other hand, when we talk of balance between two objects or among objects so we divert our discussion towards the very balance that froms the entire universe particularly and cosmos generally (Embree, 2010). This 
Independent Journal of Management \& Production (IJM\&P) ISSN: 2236-269X DOI: 10.14807/ijmp.v3i2.45

v. 3, n. 2, July - December 2012

balannce is the Moral sense that is linked to the corrosponding aesthetic sense of humans, by developing an analogy between moral and other senses, we can comprehend the moral sense. (Adorno, 1997) while its symphonic form is in Musical pieces. It is fairly not needed to develop an independent aesthetic sense faculty in terms to perceive and to appreciate beauty in this universe. The pool of basic five senses are more than enough to serve this very purpose; nonetheless, simply spotting something beautiful is not by itself sufficient to escalate its beauty.

It is for sure that perfect vision and hearing capacities are not a valid reason regarding development of this aesthetic sense, so it means that it is something extra, something additional, something that is not solely dependent upon perfection of vision and hearing and if we relate it to the perfection of vision and gearing then it means that we are limiting it to an undefined core. Updating with reference to the beauty of an object is the focus of aesthetic sense, (Wollheim, 1980) Hence, we can analogically comprehend the moral sense as providing us information of what is good. People with an operative moral sense develop a flawless impression of inexactness when they see (or imagine) somebody being mugged.

This aesthetic sense is about loving and appraising beauty and harmony in society, people around one and eventually in oneself, If one has love for beauty in life, in people, in nature, in material things, in space, then one is sensitive to own emotions, others' emotions, own environment, own development for transformation; in order to be able to live aesthetically is like living spiritually and appreciating beauty in everything exists around in surroundings, it envelops a search of beauty in the world around you, in every existing object and on top of it in your own feelings, discourse and deed, (Parakh, 2011) It consoloidates the concept of an integral and constant connection between ethics and aesthetics. Moral Values and aesthtics go hand in hand, not in their very applied sense but also in theoraticl sense (Schellekens, 2007) and while making judgement regarding beautification of an object; we take into consideration the relevant notions that are attached with the word'aesthetics' as experiences, concepts, properties, or words; (Zangwill, 2010) aesthetic attributes are those that are credited in aesthetic judgments; aesthetic experiences are those that ground aesthetic judgments; aesthetic 
Independent Journal of Management \& Production (IJM\&P) ISSN: 2236-269X DOI: 10.14807/ijmp.v3i2.45

v. 3, n. 2, July - December 2012

concepts are those that are deployed in aesthetic judgments; and aesthetic words are those that are typically used in the linguistic expression of aesthetic judgments.

In a well knitted combination, the primary concept of aesthetics is developed beneath the very existence of a society and exemplifies its being in the perspective of social norms and values, it can be named with reference to its closest context and in relaity as Social Aesthetics which is an artisitc attitude towards the world of acts (Larsen, 1999) and acts are undertaken in a social setup in which we live and pass our lives with other people, the sociology of aesthetics sets the dimension of personality development. John Dewey expresses the same as that somebody who merely appears in a state of anger by exhibiting it is not precisely expressing anger. Expression does not exemplify the real state of a person as it can be a reaction against something and that specific act cannot be named as expressive in the very right perspective of the said subject. (Dewey,1980).

Human beings in a society add value in the form of their contribution, keeping their individuality intact and this contribution advocates the mental balance, the psychological state of an individual who functions at a satisfactory emotional level and behavioral adjustment, (Thesaurus, 2012) and state of the impulses that draw these contributions in the final state. Tired, bored, fatigued, dejected and un-happy individuals cannot contribute what they are supposed to and this state shatters the social balance.

\section{Job related Stress}

Stress is a psycho-physiological process, which results from the interaction of the individual with the environment (Luthans, 1998) and results in disturbances caused to the physiological, psychological and social systems, depending upon individual characteristics and psychological processes. Organizational stress can be defined (Henry, 2008) as an emotional, cognitive, behavioral and physiological response to the aggressive and harmful aspects of work, work environment and organizational climate. It is a condition characterized by feelings of helplessness in solving tasks.

The American Institute of Stress estimates that job-related stress costs the United States industry $\$ 300$ billion annually in absenteeism costs, diminished productivity, employee turnover, workers' compensation and medical insurance \& health 
Independent Journal of Management \& Production (IJM\&P) ISSN: 2236-269X DOI: $10.14807 /$ ijmp.v3i2.45

v. 3, n. 2, July - December 2012

care expenditures are nearly fifty percent higher for workers who report high levels of stress (NIOSH, 1999) ongoing medical costs, direct income loss, transport costs and losses related to lifestyle changes can result in counter-productive workplaces and significant financial loss to employees and employers. The European Agency for Safety and Health at Work found that 28 percent of workers in the European Union reported stress-related health problems. This amounts to 41 million EU workers affected by workrelated stress each year and around 600 million working days per year lost across the EU for work-related health reasons (Ward, 2002) In addition, the British Health and Safety Executive (HSE, 1990) revealed that at least half of all days lost in the UK were due to stress related illnesses.

The cost to Britain's economy is estimated at approximately 6.7 million days lost per year, costing society between $£ 3.7$ and $£ 3.8$ billion. Job related stress is recognized world-wide as a major challenge to individual mental and physical health, and organizational health (ILO 1986). Stressed workers are also more likely to be unhealthy, poorly motivated, less productive and less safe at work, and their organizations are less likely to succeed in a competitive market. By some estimates work-related stress costs the national economy a staggering amount in sick pay, lost productivity, health care and litigation costs. (Palmer, 2004). The Health \& Safety Commission (Council, 2007) defines stress at work as: 'Stress is the adverse reaction that people have to excessive pressures or other types of demand placed upon them'. Every job brings its own pressures and demands; these are an unavoidable part of working life.

\section{Causes of Job Stress}

World Health organization in one of its report characterizes the psychological hazards at the work place and come up with the following core areas which generate a psychological imbalance among individuals at work:

The above table shows that a single cause of stress can be identified in number of ways and so is the case with the affetc of these multi-dimensional ways/identifiers on employees and consequently their performance at the work place. 
Independent Journal of Management \& Production (IJM\&P) ISSN: 2236-269X DOI: $10.14807 /$ ijmp.v3i2.45

v. 3, n. 2, July - December 2012

Table 1: \{Stressors and Identifiers\}

\begin{tabular}{|l|l|}
\hline Stressor & Identifiers \\
\hline Job content & $\begin{array}{l}\text { Lack of variety or short work cycles, fragmented or meaningless work, } \\
\text { under use of skills, high uncertainty, continuous exposure to people } \\
\text { through work }\end{array}$ \\
\hline Workload \& work pace & $\begin{array}{l}\text { Work overload or under load, machine pacing, high levels of time } \\
\text { pressure, continually subject to deadlines }\end{array}$ \\
\hline Work schedule & $\begin{array}{l}\text { Shift working, night shifts, inflexible work schedules, unpredictable hours, } \\
\text { long or unsociable hours }\end{array}$ \\
\hline Control & $\begin{array}{l}\text { Low participation in decision making, lack of control over workload, } \\
\text { pacing, etc. }\end{array}$ \\
\hline Environment and Equipment & $\begin{array}{l}\text { Inadequate equipment availability, suitability or maintenance; poor } \\
\text { environmental conditions such as lack of space, poor lighting, excessive } \\
\text { noise }\end{array}$ \\
\hline Frganizational culture \& & $\begin{array}{l}\text { Poor communication, low levels of support for problem solving and } \\
\text { personal development, lack of definition of, or agreement on, } \\
\text { organizational objectives }\end{array}$ \\
\hline Role in Organization & Role ambiguity, role conflict, and responsibility for people \\
\hline Career development & $\begin{array}{l}\text { Career stagnation and uncertainty, under promotion or over promotion, } \\
\text { poor pay, job insecurity, low social value to work }\end{array}$ \\
\hline Home-Work Interface & $\begin{array}{l}\text { Conflicting demands of work and home, low support at home, dual } \\
\text { career problems }\end{array}$ \\
\hline
\end{tabular}

(Jain, 2010)

In underlining the causes of job related stress, working conditions and Worker's personality profiles play significant role. It so happens that what is a stressful working condition for one perosn may not be the same for another person, National Institue of Occupational Health has taken the discussion further and conclude that even though the prominence of individual differences is always prevailing, but according to provided and available scientific evidences, definite working conditions, as extreme workload strains and incompatible anticipations, appear full of stress for most of the people. The principle argument jumps out of these evidences advocates for higher emphasis on working conditions as the focal cause of workplace stress (NIOSH, 1999). The same report highlights certain job conditions that may lead to stress as:

Rebecca Maxon in her article "Stress in the Workplace: A Costly Epidemic" captions stress management as the most important challenge of $21^{\text {st }}$ century. She further quoted significant job related stresses, referencing Holmes-Rahe Life Events Scale that rates the level of stress caused by scores of social, personal and 
Independent Journal of Management \& Production (IJM\&P) ISSN: 2236-269X DOI: $10.14807 /$ ijmp.v3i2.45

v. 3, n. 2, July - December 2012

occupational stress related events; as: firings, business readjustments, changes in financial status, altered responsibilities, a switch to a different line of work, trouble with the boss, variations in work hours or conditions, retirement and vacations. (Maxon, 1999).

Table 2: \{Stress related Job Conditions\}

\begin{tabular}{|l|l|}
\hline The Design of Task & $\begin{array}{l}\text { Heavy workload, infrequent rest breaks, long working hours and } \\
\text { shiftwork; hectic and routine tasks that have little inherent meaning, do } \\
\text { not utilize workers' skills, and provide little sense of control. }\end{array}$ \\
\hline Management Style & $\begin{array}{l}\text { Lack of participation by workers in decision-making, poor communication } \\
\text { in the organization, lack of family-friendly policies }\end{array}$ \\
\hline Interpersonal Relationships & $\begin{array}{l}\text { Poor social environment and lack of support or help from coworkers and } \\
\text { supervisors. }\end{array}$ \\
\hline Work Roles & $\begin{array}{l}\text { Conflicting or uncertain job expectations, too much responsibility, too } \\
\text { many "hats to wear". }\end{array}$ \\
\hline Career Concerns & $\begin{array}{l}\text { Job insecurity and lack of opportunity for growth, advancement, or } \\
\text { promotion; rapid changes for which workers are unprepared }\end{array}$ \\
\hline Environmental Conditions & $\begin{array}{l}\text { Unpleasant or dangerous physical conditions such as crowding, noise, } \\
\text { air pollution, or ergonomic problems. }\end{array}$ \\
\hline
\end{tabular}

(NIOSH, 1999)

Job related stress caused scores of psychological and physiological imbalances in a worker's personality that eventually leaves him distressed and distorted as the stress at the work place diminshes the possibility of maintaining a balance between home and work and unless this balance is gained or sorted out, a worker will not be in a position to come up with his best.

\section{Work Life Balance}

Industrial revolution (1750-1850) (Hoppit, 2011) was the period in which the ideology of work-leisure dichotomy invented and established; where work was given $1^{\text {st }}$ preference as main activity in any society and the first recognition of adult male, who in accumulation, was an employee (Thomas, 1964). On the other hand all those activitie that come under leisure were given marginal considerations and less/no importance (Voth, 2000 ;Browne, 2006; Burke, 1995). Leisure or free time is the time spent away from any professional and personal obligation, that time is meant for oneself and spent in any activity tend to provide a sense of menatal/physical relaxation,recreation and plaeasure (Andorka, 1987; Robinson, 1997). The balance between work and personal life is key for lasting growth and success; the anthropolgical definition of happiness is 
Independent Journal of Management \& Production (IJM\&P) ISSN: 2236-269X DOI: 10.14807/ijmp.v3i2.45

v. 3, n. 2, July - December 2012

minimum possible separation between work and play (Paul Krassner, 1963) in order to keep an individual healthy and productive; correspondingly an imbalance separation generates psychological disoreders, alienation and detachment towards work and life (Lambert M. Surhone, 2010).

The immediate resultant factor of this psychological disorder is multi-dimensional; the individual seems struggling with a conflicting family life (Williams, 2010) while at the same time their companies are facing odds because of their problematic behavior and paying the cost (Emslie, 2009) in terms of losses at different levels. Managers are involved in smart tasks which needs extreme mental balance, personal composure, problem solving and decision making skills; in close alignment with planning, organizing, leading and controlling as core management functions (Gomez-Mejia \& Cardy, 2008). Their productive efficency \{maximum output with least input\} surfaces in positive terms when they play their captioned role as desired/required by parent organization (Standish, 1997).

\section{Corporate World 'Nausia'}

Working dynamics and values of Corporate World has changed a lot and in this very $21^{\text {st }}$ century, Global economic recession has engulfed the companies round the world. Recession in Economics can be defined as, recession is a business cycle contraction, a general slowdown in economic activity (Meriam-Webster, 2008). Leaks and drips in economic activity generates unemploymemt, the extreme impression of a period of recession on overall employment may not be felt for many living and struggling classes. A Research study in Britain reveals that un-skilled, low-skilled, low-educated workers and the youngsters are most susceptible to unemployment in a downturn (Vaitilingam, 2010). The standard of living of those who are dependent on wages and salaries are the more affected ones by recessions as compared to those who rely on fixed incomes or social benefits.

In the very right perspective of the problems and issues cited above the corporate greed, employee exploitation, un-ethical decision making are the soring ailments eating out the health of corporate world and placing it on the top of the Mafia 
Independent Journal of Management \& Production (IJM\&P) ISSN: 2236-269X DOI: 10.14807/ijmp.v3i2.45

v. 3, n. 2, July - December 2012

list. Bruce A. Dixon captioned in his report that Corporations are immensely wealthy, taxed and regulated more lightly than human beings, protected by law from most kinds of accountability, and are immortal. A human, who kills someone, even by accident, can be held civilly or criminally liable, stripped of all property and assets, imprisoned or put to death. Corporations can poison and kill thousands at a time, without even the need for apologies. Texas alone puts a couple of people to death every month. When was the last time a corporation had its assets confiscated? Why isn't there a corporate death penalty? (Dixon, 2010 ). In fact, the Corporate world is pacing fast towards its own death and there would be a time when the corporate stalwarts will be questioned openly by the Masses for their wrong doings.

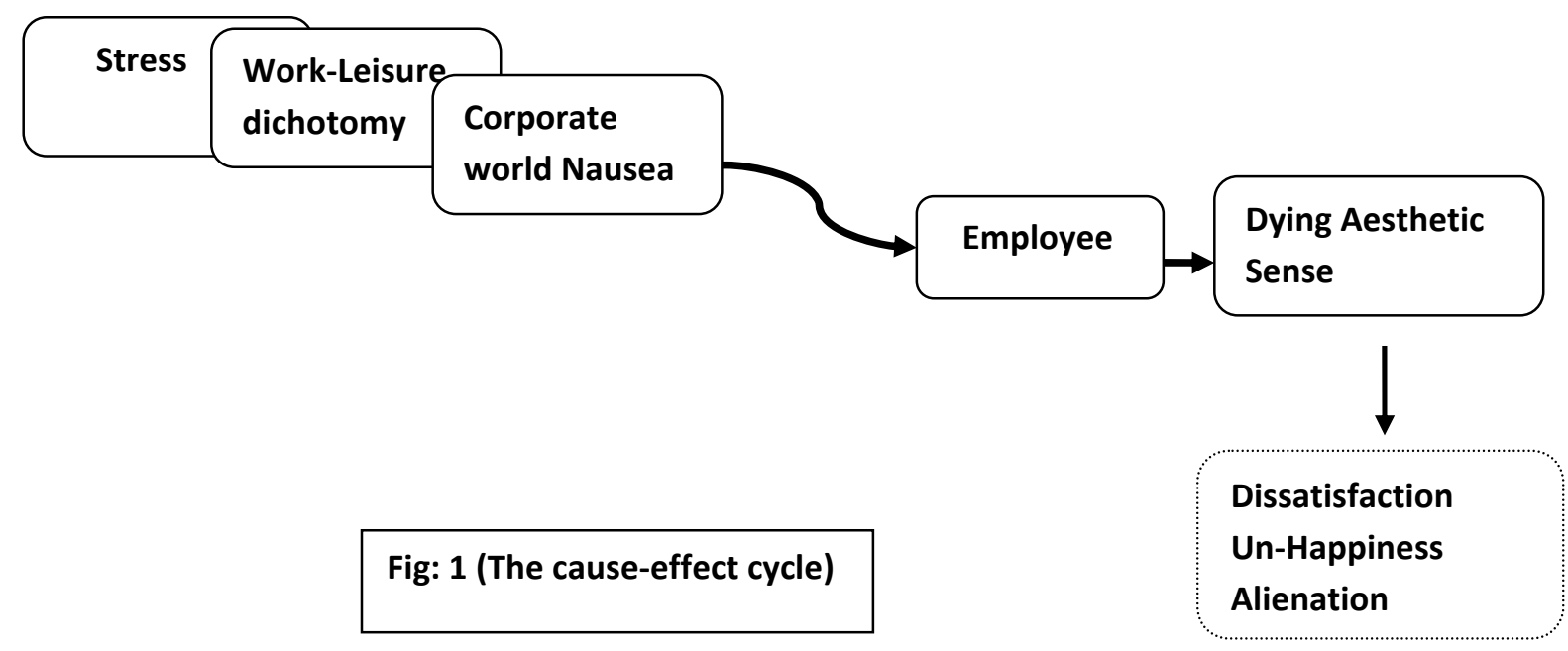

The above framework carries three major causes that have been described earlier with reference to the prominent studies, that affect an employee and consequently the affected employee starts losing his aesthetic sense. We look into the highlighted sub-categories, which describe the gradual death of aesthetic sense in a row in order to look into the relationship between the two.

Dissatisfaction or Dissatisfied employees hate the work place, they hate management as they feel that they are not being treated well and even they do not trust their Management and what is being told by their Management. They feel poorly paid, and that they are being forced to shoulder and compromise the cost of their health 
Independent Journal of Management \& Production (IJM\&P) ISSN: 2236-269X DOI: 10.14807/ijmp.v3i2.45

v. 3, n. 2, July - December 2012

compensation plan, even they develop a permanent feeling that their jobs are tarnishing the quality of their family life and they are being turned into an isolated individual with directionless life. The core of these feelings is that they feel themselves defenseless in order to turn the tables in their favor. They have constant fears of losing their jobs with the trauma that if they go for another employment opportunity then they had to come across the same aura all the way with same or similar set of problems. (Katcher, 2006) These unhappy employees cannot add any value to their jobs, to their organization and even to their families and themselves.

A poll by Known UK Recruiter Monster reveals that a majority of UK employees are dissatisfied with their jobs and they are unhappy as they feel that their contributions towards their companies are not being so appreciated as it ought to be. In addition, employees in the UK felt that their development needs were not being paid due attention, with 73 per cent claiming their managers were not investing enough in staff training or development. (Deshayes, 2011). This attitude diverts the effort of an employee towards unhappiness and displeasure and the resultant factor of this mental syndrome is frustration which eventually shatters out other relationships.

This state of unhappiness leads an individual towards depression and Depression is a state of low temper and loathing to commotion that can disturb a person's feelings, conduct, spirits and bodily well-being. (Salmans, 1997) Depressed people may feel sad, nervous, hollow, desperate, stranded, ignorant, mortified, illtempered, or agitated. They keep on and may lose interest in activities that once were pleasurable for them, they come across trackless eating habits in terms of loss of appetite or overeating, or problems while concentrating on specific task, memorizing particulars or making decisions; and may anticipate or endeavor to end their lives, sleeplessness, unnecessary slumbering, exhaustion, loss of energy, or twinges, discomforts or digestive difficulties that offer intense resistance while being treated (NIMH, 2009); eventually these depressed people do not add any value to life and most of the time their family life seems endangered as they cannot give their fullest possible input required to intact relations. They cannot play good husband, father and friend and this mental state leaves them in isolation. A mentally healthy person is prone to give his 
Independent Journal of Management \& Production (IJM\&P) ISSN: 2236-269X DOI: 10.14807/ijmp.v3i2.45

v. 3, n. 2, July - December 2012

best not only in terms of his presence with the family but also through his intellect, involvement and input. Thomas Jefferson once said, "The happiest moments of my life have been the few which I have passed at home in the bosom of my family." (Jefferson, 2011)

Unhappiness is an apparent state of depression which is a definite state of stumpy temper and antipathy to the function that may affect a person's feelings, behavior, thought process and physical balanced state (Salmans,1997). National Institute of Mental Health captioned depressed people as individual survive in a state of sadness, unhappiness, emptiness, hoplessness, regrets and hatred; they are prone to loose interest in activities that were plesurable for them (NIMH, 2009). Take the case of corporate employees work in night shifts which may increase their chances to have more earnings but it leaves these employees lonely and isolated due to lack of contact with their families and social circle (Goswami, 2012) and eventually their mode of work affect them psychology and psychophysiologically (Akerstedt, 1990). In fact the increasing demand of work generates dissatisfaction and this sense of dissatisfaction ignites sense of unhappiness (Mulhern, 1983).

Quality of work life is even a very strong area that not only affects the professioal profile of an employee but the personal profile of the same as well (Che Rose \& Beh L.S, 2006); over all work environment, behavior of supervisors, job satisfaction and organizational commitment keeps an employee happy and he strives more and places his/her share for imporvement (Sirgy, 2001); in the respective mode, if the work interfares with the workers' personl life then it appears as a sitution of depression and dejection (Ensher, 2001) which squeezes the options for decision making and the delay exaggerates depression level of the employee

Alineation refers to the estrangement that occurs in the relation between an individual and that to which he or she is relating. This break in the relations occurs in a variety of forms, such as the estrangements between an individual and his or her social community, natural environment; own self and even GOD. (Kwak, 2011); the term is further defined as a withdrawing or separation of a person or a person's affections from an object or position of former attachment (Webster, 2011). Karl Marx further elaborated 
Independent Journal of Management \& Production (IJM\&P) ISSN: 2236-269X DOI: 10.14807/ijmp.v3i2.45

v. 3, n. 2, July - December 2012

the same in his famous Theory of Alienation, can be found in his manyscripts written in the year 1844, refers to the separation of things that naturally belong together, or to put antagonism between things that are properly in harmony. In the concept's most important use, it refers to the social alienation of people from aspects of their "human nature" (Gattungswesen, usually translated as 'species-essence' or 'species-being'); He believed that alienation is a systematic result of capitalism. (Marx, 1964).

It can easily be concluded that Alienation is a permanent state of mind which governs a human in an estranged direction. In the words of Hegel, the unhappy consciousness is in a divided form aginst its own self, depart from its ownself which has already been lost and the physical existence seems meaningless (Avineri, 1972). Marx used fundamentally the identical concept to interpret the state of contemporary individuals - specifically current pay laborers - who are dispossessed of a pleasing manner of life for the reason that their life-activity, as socially productive agents, is devoid of any sentiments of collective action or satisfaction, and gives them no ownership over their own lives or their products. In contemporary society, individuals are alienated, since that their common human essence, the real co-operative activity which rationally ties them, is power-less in their lives, which are subject to an merciless power - created by them, but splitting and controlling them instead of being subject to their united will. (Gouldner, 1980)

\section{Social Disaster}

The social setup comprises of an individual and family, and the more this relationship is shattered the social balance seems in jeopardy, (Caproni , 2004) as satisfied employees blessed with flexible working hours (Anderson, 2010 ) are active and strong social members with more control over their livs outside work (Byrne,2005) and parallel conrol of their lives at the work place. It is being closely studied by oranizations round the globe that unless the family life is well in control of their employees their level of concetration or requried level of commitment cannot be obtined as they are not leading a healtheir life (Berman,2002) and 'are not maintaining a healtheir life style. Happiness and sense of satisfaction impact both the professional and personal life of an employee (Goodman, 2011) as whole human life is networked 
Independent Journal of Management \& Production (IJM\&P) ISSN: 2236-269X DOI: 10.14807/ijmp.v3i2.45

v. 3, n. 2, July - December 2012

and we cannot pull apart the loops to make separate chains (Urry, 2003). A survey reveals that every third of UK employees are unhappy in their jobs and it even shows in their personal lives as well (Oprita, 2011). The happy worker hypothesis (Stahl, 2004) is very valid in terms to have peope full of life so that they may lead their social lives with strong personality (Bowling, 2007).

The increasing rate of workers' suicide at Foxconn China exposes the workplace design and atmospehre; Xiang Qian committed suicide on Jnuary $3^{\text {rd }} 2010$; Ma's sister, Ma Li Qun, 22, also worked for Foxconn and said that they work under extreme pressure and were not allowed to talk during work, even more they were not permitted to look around and their timings were noted through a stop watch and heavily fined for any mistake. She said her brother was orally and expressively ill-treated by Foxconn supervisors. "My brother wasn't happy at Foxconn. In the beginning he worked quite slowly and his superiors would scold him. They made him clean the toilets for a month." The Ma family does not believe that their son committed suicide and claim that he was murdered, although it's not clear if there is any evidence to support such a claim (Loyd,2010). There has been an open uproar over the suicides of 24 employees at France Telecom due to extensive stress. The most recent victim, a former law student aged 32 years, jumped out of her office window leaving suicide note for her father.

Another blamed "management by terror" for driving him above the levels, "I am committing suicide because of my work at France Telecom. That's the only reason (Corkindale, 2009). The economic recession in the year 2008 in USA had turned out to be the year of depression with increasing number of suicide due to job related complexities, competitiveness and joblessness (Al-Hail, 2009) It is not only the case with rank and file employees but the suicide of Peregrine Financial CEO really caused alarm as financial irregularities and some accounting discrepancies pushed him to take his life (Suhr, 2012). Sudharshan was reprimended and threatened by the project manager just a few minutes before he dropped himself from the $11^{\text {th }}$ floor and died on the sopt (Reporter, 2010). In this very context, the alarming increase in suicide cases in Japan, crossed 32,000 in the year 2006, when probed appeared that many employees were forced to work harder due to ongoing business reformation; frequent cases of 
Independent Journal of Management \& Production (IJM\&P) ISSN: 2236-269X DOI: 10.14807/ijmp.v3i2.45

v. 3, n. 2, July - December 2012

suicide have officially been acknowledged as related to depression originating from overwork over a decade (Mutsuhiro Nakao, 2008) while government has intorduced many counselling and rehabilitation schemes to reduce the number of suicide and suicidal attempts.

A single case of suicide in any society exposes the dents in socio-economical and socio-cultural cover and exposes the strength of inter personal relationship at different levels, suicide is intentionaly causing one's own death under the influence of depression, problematic relationship and economic difficulties (Stone, 2001). The mental approach before suicide or detachement and/or loss of personal identity for a while; are the relevant outcomes that exemplify the mental state of the one going for such an extreme attempt and in fact it is absence of aesthetic sense, the sense of beauty, contention and peace.

Work related problems disturb and disrupt whole family and under stress employee cannot control these two worlds moving in opposite directions (Ireland, 2006); especially in the case of project based employment as it needs more time and extra efforts and employees in this specific cadre are exposed to more work-family encounters and emotional collapse (Francis, 2004). Actually, if we look closely then high rates of divorce, lower rates of re-marriages, single parents/zero parents syndrome are some of the social indicators that tell us the changing situation of the family in these changing circumstances (Burgess, 1994); on the contrary, the living families are experiencing more situations of domestic violence, serious depression, alsohol abuse, suicidal attempts etc., as an outcome of demanding occupational responsibilities (PEF, 2006).

The entire situation seems vague as technological advancements and inventions have further developed a corner of isolation for an individual. Despite, stress, dissatisfactions and imbalance work-life, one is more exposed to couple of those gadgets that have deprived him of his very privacy and a chance to maintain sound intra-personal and interpersonal relationship. Stress, dissatisfaction and alienation envelops an employee in such a way that he/she cannot act in accordance with his/her personal and social requirements. We need to understand that every human is living 
Independent Journal of Management \& Production (IJM\&P) ISSN: 2236-269X DOI: 10.14807/ijmp.v3i2.45

v. 3, n. 2, July - December 2012

under the cover of many facets, as an employee, Father, Husband, Son and someone else for many some ones. It is to be understood that the social structure is already diverting towards Isolation ; technological advancements has created more rooms for a person to be a single person as nowadays, a person passes more time with his mobile, iphone, ipod, Internet and TV as compared to his interaction with other individual. A general survey reveals that average adult Americans feel more socially isolated because of the rise of the internet and cell phones (OLSEN, 2009). Our subject matter is not technological advancements and its impact on social life but the point is that these gadgets which are now a regular part of our lives have reduced many options to be with one another as most of the leisure time is being spent with these.

The time we have, if not passed in a way in which it must be then it will definitely be a disaster; work-life balance is in totters and people are compromising on so many things as there are very meagre opportunities in this economically dented era. Psychoanalysts detect improbability as the foremost approach to life in the postmodern society. (Reich, 2010) The amount of pressure executed by the society on the humans caused this uncertainty. It is the uncertainty to fail, nonetheless the fears of limitations, fear of not achieving what is expected by the society and a never ending of having being recognized in all concerned areas and spheres of life. A non-stop competition is the tag mark of today's society. Appearance, occupation, education of the children everything is compared to a media staged ideal. Everything should be perfect, because this deep-rooted abhorrence to all normal, the pathological pursue to excellence - these are hoary customs. Whoever wants more - on the job, from the partner, from the children, from themselves - will one day be burned out and empty inside. He is then faced with the realization that perfection does not exist (Poelchau, 2010) but till that time there will not be any room to hide and any place left to go.

\section{CONCLUSION}

The prime focus of this paper is to establish arguments in favour of the captioned hypothesis that work related problems and dying aesthetic sense of corporate employees. The literature presented above is a candidi selection of those research pieces that seemed more opt and adequate to prove the point. It is such a wide topic 
Independent Journal of Management \& Production (IJM\&P) ISSN: 2236-269X DOI: 10.14807/ijmp.v3i2.45

v. 3, n. 2, July - December 2012

that much can be written with reference to related context but our fundamental aim was to establish the conceptual ground for better understanding of aesthetic coupled with stress and work-life balance.

All the research articles refered to support the point are well in accordnace with the said subject and most of them are reserch studies based upon empirical findings. The intrinsic concentration was on the relatonship between an employee and employer, the ups-downs of this relationship and its impact on the personal life of the same employee including his family and social circle, the growing number of suicide cases, sense of alineation, depression, frustration and isolation is stretching living opportunitities for a corporte employee till the last point of survival.

The primary findings presented in this paper can be summrized as:

- Work related stress and work life balance are the two core causes that affect an employee's professional as well as personal life

- Dissatisfaction, unhappiness and alienation are the derived affects of the captioned causes.

- Social life and social circle is experiencing extreme damages owing to imbalance work-life situations

- High paid workers are committing suicide and the rate of committing suicide is increasing by every passing day in industrialized, established and strong economies vitalizes the missing link between man and society.

As captioned much has been written and much can be writtent, the need is to go for quantitative, empirical, positivist research studies to cover this sensitive area in a concrete manner. Interestingly, findings in many researches contain essense of generalizability as we talk of human equation and this equation seems identical in its very context. There ar emany studies available that discuss work related stress but there is still a significant room avaialble to link the factory with the family.

\section{References}

ADORNO, T. W. (1997). Aesthetic Theory. Minneapolis: University of Minnesota Press. 
Independent Journal of Management \& Production (IJM\&P) ISSN: 2236-269X DOI: 10.14807/ijmp.v3i2.45

v. 3, n. 2, July - December 2012

AHMAD, S. I. (2009). Impact Of Stress On Employee Productivity, Performance And Turnover; An Important Managerial Issue. International Review of Business Research Papers, v. 5 n. 4, p. 468-477.

AKERSTEDT, T. (1990). Psychological and physiological effects of shift work. Scandinavian Journal of Work and Environmental Health, v. 16, n.1, p. 67-73.

Al-HAIL, A. (Opinion Editorials, May 2009). The Human Cost of US recession. AlJazeerah: Cross-Cultural Understanding.

ALI, M. Z. (2008). Job Stress among Software Professionals in Pakistan: A Factor Analytic Study. Journal of Independnt Studies and Research (MSSE), p. 1-14.

ANDERSON, C. K. (2010). Doing more with less? Flexible working practices and the intensification of work. Human Relations vol. V. 63, n. 1, p. 83-106 .

ANDORKA, R. (1987). Time budgets and their uses. Annual Review of Sociology v. 13, p. $149-164$.

AUTHOR, S. (2009). Balance. In E. Board, The American Heritage ${ }^{\circledR}$ Dictionary of the English Language: Fourth Edition. New Jersy: Houghton Mifflin Company.

AVINERI, S. (1972). Hegel's Philosophy of Right and Hegel's Theory of the Modern State.

BERMAN, E. (2002). Work/life balance. Engineering Management Review, IEEE, v. 30 , n. 4 , p. $116-118$.

BLANCHARD, M. H. (2012). Work Life Balance? Obstetrics \& Gynecology, v.119, n. 1, p. 177-179.

BOSWELL, W. A.-B. (2007). The Use of Communication Technologies After Hours: The Role of Work Attitudes and Work-Life Conflictt. Journal of Management, v. 33, n.4, p. 592-608.

BOWLING, N. (2007). Is the Job Satisfaction-Job Performance Relationship Spurious: A Meta-Analytic Examination. Journal of Vocational Behavior, v. 71, p. 167-185.

BROWNE, K. (2006). Introducing Sociology for AS Level. Malden, MA: Polity.

BURGESS, R. L. (1994). The family in a changing world A prolegomenon to an evolutionary analysis. Human Nature, v. 5, n. 2, p. 203-221.

BURKE, P. (1995). The Invention of Leisure in Early Modern Europe. Past and Present, n. 146 , p. $137-138$.

BYRNE, U. (2005). Work-life balance: Why are we talking about it at all? Business Information Review, v. 22, n. 1, p. 53-59.

CAPRONI, P. (1997). Work/Life Balance. The Journal of Applied Behavioral Science v. 1, n. 33, p. 46-56.

CAPRONI, P. J. (2004). Work/Life Balance You Can't Get There From Here. Journal of Applied Behavioral Science, v. 40, n. 2, p. 208-218. 
Independent Journal of Management \& Production (IJM\&P) ISSN: 2236-269X DOI: 10.14807/ijmp.v3i2.45

v. 3, n. 2, July - December 2012

CHE ROSE, R.; BEH L.S, U. J. (2006). An Analysis of Quality of Work Life and CareerRelated Variables. American Journal of Applied Sciences, v. 3, n.12, p. 2151-2159.

CORKINDALE, G. (5:38 PM October 7, 2009). Why Are France Telecom Workers Committing Suicide? HBR Blog Network.

COUNCIL, P. C. (2007). Management of Work-Related Stress. Health \& Safety Performance Standard 15: (HSPS15), 43.

DENNEY, C. (2000). At the Temple of Art: the Grosvenor Gallery, 1877-1890. Fairleigh Dickinson University Press.

DEPARTMENT, P. H. (2006). Occupational Stress Fact Sheet. Newyork: New York State Public Employees Federation.

DESHAYES, C. (19th May 2011). Majority of UK employees dissatisfied with managers. Learndirect.com.

DEWEY, J. (1980). Art as Experience (1934): Republished (1980). New York: Berkley Publishing Group.

DICTIONARY, M.-W. (2011). Aesthetics:Definition 1. Meriam-Webster Dictionary online. DIXON, B. A. (3-10-2010 (13:29)). In the 21st Century, It's Black America VS Corporate America. Black Agenda Report.

EFILW. (2007). Work Related Stress. Dublin: European Foundation for the Improvement of Living and Working Conditions.

EMBREE, H. R. (2010). Handbook of Phenomenological Aesthetics (Series:

Contributions To Phenomenology, Vol. 59). New York : Springer.

EMSLIE, C. (2009). Live to work or work to live. Harvard Educational Review , v.16, n. 1, p. 151-172.

ENSHER, E. J.-V. ( 2001). An examination of work and personal life conflict, organizational support, and employee health among international expatriates. International Journal of Intercultural Relations, v. 25, n. 3, p. 261-278.

FINCHAM, B. (2008). Balance is Everything: Bicycle Messengers, Work and Leisure. Sociology August 42: , 618-634.

FRANCIS, H. L. (2004). The work $\square$ life experiences of office and site $\square$ based employees in the Australian construction industry . Construction Management and Economics, v. 22, n. 9, p. 991-1002.

GALERIA ALVAREZ, P. C. (1974). Aesthetic Synthesis (En), Ed. New York: Selected Artists Galleries.

GOMEZ-MEJIA, L. R.; CARDY, D. B. (2008). Management: People, Performance, Change, 3rd edition. Newyork: McGraw-Hill.

GOODMAN, A. (2011). Work-Life Balance. In R. D. Ehrenfled, Physicians' Pathways to Non-Traditional Careers and Leadership Opportunities (pp. 25-34). New York: Springer 
Independent Journal of Management \& Production (IJM\&P) ISSN: 2236-269X DOI: 10.14807/ijmp.v3i2.45

v. 3, n. 2, July - December 2012

GOSWAMI, R. (2012). Shift work and its effect on on social and personal life of shift workers. International Journal of Research in Management, Economics and Commerce, v. 2 , n. 5 , p. $47-63$.

Gottlied, B. A. (2004). Metaphysics (Translated Version). Dietrich Scehgimann Reprints. GOULDNER, A. W. (1980). Alienation: From Hegel to Marx - Chapter 6, The Two Marxisms. New York: Oxford University Press.

HENRY, O. (2008). Occupational Stress in Organizations. Journal of Management Research, v. 8, n. 3, p. 123-135.

HIGGINS, T. W. (2005). Workplace Stress: Etiology and Consequences. Journal of Workplace Behavioral Health, v. 21, n. 2, p. 89-97.

HOPPIT, J. (2011). The Nation, the State, and the First Industrial Revolution. Journal of British Studies , p. 307-331.

HUGHES, S. A. (2002). Work-life balance . London: Spiro.

IRELAND, J. (2006). Ideas for Preventing Work-Related Family Problems. Occupational and Environmental Medicine.

JAIN, S. L. (2010). Health Impact of Psychosocial Hazards at Work: An Over View. World Health Organization Report, p. 1-136.

JEFFERSON, T. (2011). Quotation. http://sayings.funnyjunkz.com/family-quotes-andsayings/.

KANT, I. (1964). The Critique of Judgement. Oxford: Oxford University Press.

KANT, I. (1999). Critiqur of Pure Reason: English Translation by: Paul Guyer and Allen Wood. Cambridge University Press.

KATCHER, B. L. (1-9-06). Why your employees hate you and what you can do about it. Pre-publication draft manuscript.

KER, P. (2003). Work-life balance. Hong Kong : Human Resources Section, University of Hong Kong.

KWAK, D. C. (2011). New World Encyclopedia. Paragon House Publishers.

LAMBERT M.; SURHONE, M. T. (2010). Work-Leisure Dichotomy. VDM Verlag Dr. Mueller e.K.

LARSEN, L. B. (1999). Social aesthetics. London.

LOYD, C. W. (June 1, 2010). Rash of Suicides in China where Apple Products are Produced. abc NEWS.

LUTHANS, F. (1998). Organizational Behavior. Boston: McGraw-Hill:.

MARX, K. (1964). Economic and Philosophic Manuscripts of 1844. New York: International Publisher. 
Independent Journal of Management \& Production (IJM\&P) ISSN: 2236-269X DOI: 10.14807/ijmp.v3i2.45

v. 3, n. 2, July - December 2012

MATHUR, D. P. (2011). A study on Impact of Stress on Managers of Manufacturing Unit of District Kota. International journal of research on management, economics and commerce, v. 2, n. 1, p. 92-99.

MAXON, R. (1999). Stress in the Workplace: A Costly Epidemic. Fairleigh Dickinson University publications.

MCDOUGALLB, G. A. (2004). Work-life balance. Public Management Review Volume 6, Issue 3, 377-393.

MEGLINO, B. (1977). Stress and Performance: Are They Always Incompatible? Supervisor Management, v. 22, n. 3, p. 2-12.

MERIAM-WEBSTER. (19-11-2008). Recssion. Merriam-Webster Online Dictionary.

MERRIAM-WEBSTER. (2012). Aesthetics. In Merriam-Webster, Merriam-Webster Dictionary. Merriam-Webster.

MULHERN, T. J. (1983). Burnout and dependency: Awakening in the ARM of the wire frame surrogate. The Journal of Behavioral Health Services and Research, v. 10, n. 1, p. 27-30.

MUTSUHIRO NAKAO, T. T. (2008). A proposed approach to suicide prevention in Japan: the use of self-perceived symptoms as indicators of depression and suicidal ideation. Environ Health Prev Medicine, v. 13, n. 6, p. 313-321.

NEDOZCHIWIN, G. (1972). Marxism \& Art: Writings in Aesthetics and Criticism. David McKay Company, Inc.

NIMH. (2009). Depression. National Institute of Mental Health Journal.

NIOSH. (1999). Stress at Work. DHHS (NIOSH) Publication Number 99-101.

OLSEN, S. (NOv 5th 2009). Does Technology Reduce Social Isolation? The Newyork Times.

OPRITA, A. (2011). A Third of UK Employees Unhappy in Their Job: Poll. CNBC.com.

PALMER, S. C. (2004). A model of work stress. Counselling at Work-Winter.

PARAKH, N. (2011). Developing Aesthetic Sense.

http://www.gnosticcentre.com/link_files/subproject_aesthetic_sense_neera.htm.

PARKER, D. H. (2003). The Principles Of Aesthetics. Michigan: UNiversity of Michigan.

PAUL KRASSNER, H. A. (1963). An impolite interview with Paul Krassne. The Realist: 41, 24.

PILLE, M. (March 2010). Do You Have Dissatisfied Employees? Inter Business Issues. POELCHAU, N. (2010). Interview: wer lassen kann, wird gelassen. In: Stern no. 11.

RAHIM, S. H. (2010). Emotional Intelligence and Stress:An Analytical Study of Pakistan Banks. International Journal of Trade, Economics and Finance, v. 1, n. 2, p. 194-199. 
Independent Journal of Management \& Production (IJM\&P) ISSN: 2236-269X DOI: 10.14807/ijmp.v3i2.45

v. 3, n. 2, July - December 2012

REPORTER, S. (August 20, 2010 ). TCS Bangalore employee Sudarshan Commits suicide. http://www.dexternights.com/2010/08/20/tcs-bangalore-employee-sudarshancommits-suicide/.

ROBINSON, J. P. (1997). Time for Life: The Surprising Ways Americans. Pennsylvania: Pennsylvania State University Press.

SALMANS, S. (1997). Depression: questions you have - answers you need. People's Medical Society.

SCHELLEKENS, E. (2007). Aesthetics and Morality. London: Continuum International Publishing Group Ltd ISBN: 9780826497628.

SHAIN, D. M. (1999). The Impact of Stress on Employees. Public health agency of Canada.

SHAIN, M. (1999). The role of the workplace in the production and containment of health costs: The case of stress-related disorders. Leadership in Health Services, v. 12, n. 2, p. 1-7.

SIRCELLO, G. (1975). A New Theory of Beauty. Princeton Essays on the Arts.

Princeton, NJ: Princeton University Press.

SIRCELLO, G. (1989). Love and Beauty. Princeton, NJ: Princeton University Press.

SIRCELLO, G. (1993). How Is a Theory of the Sublime Possible? Journal of Aesthetics and Art Criticism, v. 51, n. 4 , p. 541-550.

SIRGY, M. J. (2001). A new Measure of Quality of Work Life based on Need Satisfaction and Spillover Theories. Social Indicators Research, v. 55, p. 241-302.

STAHL, M. J. (2004). Happy worker hypothesis. Encyclopedia of Health Care Management. , p. 311.

STANDISH, B. (1997). Economics: Principles and Practice. South Africa: Pearson Education.

STONE, G. (2001). Suicide and attempted suicide. New York, NY: Carroll \& Graf. SUBBULAXMI, M. S. (2002). Productivity and Stress. Management , v. 2, n. 3, p. 27-30. SUHR, D. W. ( 07/10/12 11:05 PM ET). Peregrine Financial CEO Left Suicide Note, 'Caused Alarm'. http://www.huffingtonpost.com/2012/07/10/russell-wasendorf-srpfgbest-suicide-note_n_1663139.html.

THESAURUS. (2012). Mental Balance. Princeton: Princeton University, Farlex Inc. THOMAS, K. (1964). Work and leisure in pre-industrial society. Past \& Present, p. 5062.

URRY, J. (2003). Social networks, travel and talk. The British Journal of Sociology, v. 54 , n. 2, p. 155-175.

VAITILINGAM, R. (2010). "Recession Britain: New ESRC report on the impact of recession on people's jobs, businesses and daily lives. Economic and Social Research Council. 
Independent Journal of Management \& Production (IJM\&P) ISSN: 2236-269X DOI: 10.14807/ijmp.v3i2.45 v. 3, n. 2, July - December 2012

VEJ, K. B. (2011). Social Aesthetics. European Doctoral Seminar (http://www.eurodocsem.net/calender_2010/social_aesthetics/).

VOTH, H.-J. (2000 ). Time and Work in England 1750-1830. Oxford University Pres(2002). Work-Related Stress, Quitting Intentions and Absenteeism. IZA Discussion Papers 493, The Future of Labour, 2-29.

WEBSTER, M. (2011). Definition. In Meriam Webster Dictionary. Meriam WebsterIncorporated.

WILLIAMS, J. (2010). The three faces of work-family conflict the poor, the professionals, and the missing middle center. Center for American Progress, Hastings College of the Law.

WILLIAMS, J. (2000). Unbending gender. Why family and work conflict and what to do about it. New York, NY: Oxford University Press.

Wollheim, R. (1980). Art and its objects. Cambridge University Press.

XUXIAO, W. (2010). Aesthetic Education and Human's Comprehensive Development. Beijing: China People University.

ZANGWILL, N. (2008). Aesthetic Judgment. Stanford Encyclopedia of Philosophy, 0228-2003/10-22-2007. Retrieved 07-24-2008.

ZANGWILL, N. (2010). Aesthetic Judgmen. The Stanford Encyclopedia of Philosophy (Fall 2010 Edition). 